\title{
HEALTH PROMOTION BY ADEQUATE WATER INTAKE AND ASSESSMENT OF BEVERAGES CONSUMPTION AMONG UNIVERSITY STUDENTS
}

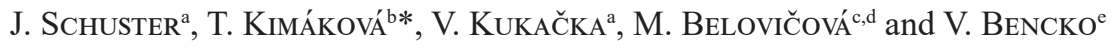 \\ ${ }^{\mathrm{a}}$ Department of Physical Education and Sport, Faculty of Education, University of South Bohemia, Na Sádkách \\ 2a/305, České Budějovice. The Czech Republic \\ ${ }^{b}$ Department of Public Health and Hygiene, Faculty of Medicine, Pavol Jozef Šafárik University in Košice, \\ Šrobárova 2, 04180 Košice. Slovakia \\ ${ }^{\mathrm{c}}$ St. Elizabeth University of Health and Social Work, Palackého 1, 81102 Bratislava. Slovakia \\ ${ }^{\mathrm{d}}$ Department of Nursing, Institute of Social Sciences and Healthcare bl. P. P. Gojdič, Jilemnického 1/A, 08001 \\ Prešov. Slovakia \\ ${ }^{\mathrm{e}}$ Institute of Hygiene and Epidemiology, First Faculty of Medicine, Charles University and General University \\ Hospital in Prague, Studničkova 7, 12800 Prague 2. The Czech Republic
}

(Received: 29 March 2020; accepted: 17 June 2020)

\begin{abstract}
The behaviour regarding the fluid intake in adolescents and young adults is an important issue, since these data may provide information about the health consciousness of the next generation. Inappropriate daily beverages intake for a long period can have adverse effects on human health. Positive effects of maintenance of good hydration are known in the prevention of chronic diseases like urolithiasis, bladder or colon cancer, hypertension, obesity, or constipation. In the present study, we examine the various factors of beverage intake by university students. Data from 3020 students of the Czech and Slovak universities were collected in 2016-2018 to evaluate their daily fluid intake and the characteristics of beverage consumptions. We found that gender, country, frequency of daily water intake, nutrition literacy, and some other factors influence whether a student reports having a daily water intake of more than 1.5 litres. Our respondents have preferences for beverages, based on taste and health effects primarily, prices and availability were secondary. We present the suggestions for a more balanced beverage intake for the studied age group.
\end{abstract}

Keywords: water, beverage intake, survey, prevention, university students

The behaviour regarding the fluid intake in adolescents and young adults may provide information about the health consciousness of the next generation. Adequate fluid intake is important for human health and survival, including maintaining brain function. The volume, composition, and distribution of body fluids have profound effects on cell function. Water plays an essential role in the body cells and tissues for breathing, digestion, removal of waste, or regulation of the body temperature. Dehydration can result in headaches, poor concentration, reduced short-term memory, changes in mood states, or can have a negative impact on physical performance. Insufficient daily fluids intake for a long period has been linked to increases in risk for urinary tract infections, dental disease, broncho-pulmonary disorders, constipation, kidney stones, and impaired cognitive function. High fluid intake can decrease the risk of urinary tract stones, colon and urinary tract cancer, or mitral valve prolapse (Balaghi et al., 2011; Park et al., 2012; An \& McCaffrey, 2016; MaliK, 2019).

\footnotetext{
* To whom correspondence should be addressed.

Phone: +42155 234 3202; e-mail: tatiana.kimakova@upjs.sk
} 
Ministry of Health of the Czech Republic provides a national recommendation in the range of 2 litres (females) to 2.5 litres (males) of fluids per day, $80 \%$ of which should come from beverages (i.e. 1.6 and 2 litres, respectively). The Public Health Office in Slovakia provides a national recommendation for children from the age of ten and adults for 2-2.5 litres of fluid per day. The water requirements for individuals can vary each day regarding physical activity, dietary contents, water losses, capacities of kidneys, or climates (RosBORG \& KoŽíŠEK, 2016; PHA SR, 2018).

KUKAČKA (2010) analysed the lifestyle of 1150 students of the University of South Bohemia in the Czech Republic aged 19 to 26 years. He found that the proportion of students with fluid consumption of less than 1.5 litres per day was 57\%. Approximately 2 litres of water per day was reported by $23 \%$ of students, the optimal intake, which exceeds 2 litres per day, was observed for $20 \%$ of the students. JAKUBíkoví (2010) presented the daily intake of more than 2 litres by $17 \%$ of students of the Department of Nursing of the University of Prešov, Slovakia $(n=116)$. An intake of only $0.25-0.5$ litres of fluids per day was reported by $27 \%$ of students. ŠRAMKOVÁ and KoPČEKOvÁ (2005) reported the daily fluid intake more than 2 litres by $26.4 \%$ of university students in Nitra, Slovakia ( $n=144)$.

NISSENSOHN and co-workers (2013) presented twelve studies on beverages and water intake of healthy adults in European countries. Regarding plain water intake, the values varied from 1.243 litres per day in Belgian women to 0.483 litres per day in Swedish men. The similar values across the studies were obtained by mineral water, coffee, and tea. Crosssectional surveys among adults in 13 countries worldwide for the total fluid intake from drinking water and beverages were evaluated by FERREIRA-PÊGO and co-workers (2016). Statistical difference was found in total fluid intake between countries but not between genders. BLOCK and co-workers (2013) provided a qualitative study of beverage consumption among US college students. They found that students have strong preferences for beverages, based on taste and price primarily, health effects were secondary. The sample of 50 university students with normal weight and diverse ethnic backgrounds in Canada was analysed by VANDERLEE and co-workers (2018). Sugar-sweetened beverages, coffee, and tea were among the most frequently consumed beverages consumed in large volumes.

The objectives of our paper are:

(1) To determine the differences in fluid intake and beverage consumption between the Czech and Slovak university students.

(2) To compare the results obtained with those from other studies.

(3) To describe the suggestions for healthy drinking of the age group studied.

\section{Materials and methods}

We collected data at the beginning of the academic years 2016/2017, 2017/2018, and 2018/2019 (in the autumns) by questionnaires at 4 universities in the Czech Republic and Slovakia. Data from 3020 students (1221 males and 1799 females) were obtained at JU České Budějovice, the Czech Republic (826 students, 223 males, and 603 females), UPJŠ Košice, Slovakia (418 students, 126 males, and 292 females), VŠP Jihlava, the Czech Republic (550 students, 90 males, and 460 females), VUT Brno, the Czech Republic (1226 students, 782 males, and 444 females). The study involved in total more females $(59.57 \%)$ than males $(40.43 \%)$. 
The questionnaire included 27 multiple choice closed-type questions regarding the volumes, frequencies, and sources of water consumption per day, the knowledge of students about healthy drinking, and the most favourite beverage. Participants reported the frequency of intake (no consumption - 0 , very rare consumption -1 , several times a month -2 , several times a week -3 , or daily consumption -4 ) for 14 categories of beverages (plain tap water, plain non-carbonated packaged water, tea, fruit/vegetable juices, coffee, regular soda or pop, sugar-sweetened beverages, flavoured water, energy drinks, diet soda or pop, sports drinks, unsweetened milk, and chocolate or sweetened milk). The categories of beverages were taken from available beverage frequency questionnaires (FERREIRA-PÊGO et al., 2016; VANDERLEE et al., 2018). In our statistical analysis, we unified the categories of unsweetened milk, chocolate, or sweetened milk to a single category of milk and milk drinks. Moreover, the place of the highest volume of beverages consumed (home or dormitory, school, restaurant, or cafeteria) was given by respondents. The questions about gender, year of study, and study area were also included. We did not explore the physical activity in the questionnaire; however, we have reported the answers of students of the Department of Physical Education and Sport, who are analysed in the group of students of Humanities and Arts.

Analysis of data was performed by using Microsoft Excel and IBM SPSS Statistics 25. Categorical variables have been represented as frequencies. Chi-square statistics were used to confirm the statistical difference between groups of students for categorical qualitative variables. Statistical significance at $* \mathrm{P}<0.05 ; * * \mathrm{P}<0.01, * * * \mathrm{P}<0.001$ were considered in our analysis.

Logistic regression allows us to assess the impact of a set of variables on a categorical dependent variable. Our analysis with logistic regression focuses on establishing relationships between the binary outcome (measured by the variable with 0 indicating water intake less than 1.5 litres and with 1 indicating equal or more than 1.5 litres) and students' characteristics that might have affected the water intake equal or more than 1.5 litres, namely:

- $\quad$ gender $(0-$ man, 1 - woman),

- $\quad$ country ( 0 - The Czech Republic, 1 - Slovakia),

- $\quad$ year of study (first, second, third, fourth, fifth, $\mathrm{PhD}$ study),

- $\quad$ study area (Medicine and Health Sciences, Engineering and Technologies, Natural Sciences, Humanities and Arts),

- frequency of daily water intake (1-4 times per day, 5-8 times per day, 9-12 times per day, more than 12 times per day),

- $\quad$ knowledge about recommended daily water intake (less than 1 litre, 1-1.5 litres, more than 1.5 litres up to 2 litres, more than two litres),

- $\quad$ knowledge about the coffee contribution to daily water intake ( 0 - yes, 1 - no),

- factors of beverage preferences (taste, health effects, price, availability),

- regularity of drinking during the day (regularly, not regularly),

- $\quad$ taking the water to the school (yes, more yes, more no, no),

- $\quad$ place of the most water intake (home or dormitory, school, restaurant, or cafeteria).

\section{Results and discussion}

Questionnaires of 3020 university students in the Czech Republic and Slovakia were analysed to evaluate their daily fluid intake. The percentages and absolute frequencies of participants regarding gender, year of study, and study area are illustrated in Table 1. 
Table 1. Characteristics of participants

\begin{tabular}{|c|c|c|c|}
\hline \multirow[t]{2}{*}{ Characteristics } & \multicolumn{3}{|c|}{ Absolute and relative frequencies of students } \\
\hline & $\begin{array}{c}\text { Total } \\
\text { (Proportion, \%) } \\
n=3020\end{array}$ & $\begin{array}{l}\text { The Czech Republic } \\
\text { (Proportion, \%) } \\
n=2602\end{array}$ & $\begin{array}{c}\text { Slovakia } \\
\text { (Proportion, \%) } \\
\mathrm{n}=418\end{array}$ \\
\hline \multicolumn{4}{|l|}{ Gender } \\
\hline Male & $1221(0.404)$ & $1095(0.421)$ & $126(0.301)$ \\
\hline Female & $1799(0.596)$ & $1507(0.579)$ & $292(0.699)$ \\
\hline \multicolumn{4}{|l|}{ Year of study } \\
\hline First & $720(0.238)$ & $613(0.236)$ & $107(0.256)$ \\
\hline Second & $619(0.205)$ & $539(0.207)$ & $80(0.191)$ \\
\hline Third & $833(0.276)$ & $756(0.290)$ & $77(0.184)$ \\
\hline Fourth & $374(0.124)$ & $328(0.126)$ & $46(0.110)$ \\
\hline Fifth & $348(0.115)$ & $283(0.109)$ & $65(0.156)$ \\
\hline $\mathrm{PhD}$ & $126(0.042)$ & $83(0.032)$ & $43(0.103)$ \\
\hline \multicolumn{4}{|l|}{ Study area } \\
\hline Medicine and Health Sciences & $303(0.100)$ & $271(0.104)$ & $32(0.077)$ \\
\hline Engineering and Technologies & $1028(0.340)$ & $1028(0.395)$ & $0(0.000)$ \\
\hline Natural Sciences & $363(0.120)$ & $186(0.072)$ & $177(0.423)$ \\
\hline Humanities and Arts & $1326(0.440)$ & $1117(0.429)$ & $209(0.500)$ \\
\hline
\end{tabular}

The water intake, frequency of water intake, and knowledge about recommended daily intake in litres per day reported by the Czech and Slovak students are illustrated in Figure 1. Fluid intake exceeding 2 litres per day was observed for $24.6 \%$ of all students, $26.0 \%$ of the Czech students, and $16.1 \%$ of the Slovak students. Fluid intake of less than 1 litre per day was observed for $14.1 \%$ of all students, $13.1 \%$ of the Czech students, and $20.1 \%$ of the Slovak students. The chi-square statistics on 3 degrees of freedom $(\mathrm{df})$ for the volumes of water consumption, the frequencies of water consumption, and the knowledge about recommended daily intake between groups of the Czech and Slovak students are described in Figure 1.

Regarding the most consumed beverages by students, they prefer tap water, tea, milk and milk drinks, fruit/vegetable juices, and coffee (see Table 2). 39.6\% of students consume sugar-sweetened beverages and $12.1 \%$ drink energy drinks. The chi-square statistic on 10 degrees of freedom for the most consumed beverages between groups of the Czech and Slovak students is $27.138\left(\mathrm{P}=0.004^{* *}, \mathrm{n}=3020\right)$. The plain tap water is consumed by a higher proportion of the Czech students; the plain non carbonated packaged water is drunk by a higher proportion of Slovak students. The relative frequencies of the consumed types of beverages by students are illustrated in Figure 2.

We performed logistic regression with a dichotomous dependent variable (water intake less than 1.5 litres and water intake equal or more than 1.5 litres). Our predictor independent variables were categorical (gender, country, study area, knowledge about recommended daily intake, knowledge about coffee contribution, factors of beverage preferences, the regularity of drinking, taking the water to the school, and place of the most water intake) or ordinal (year of study, frequency of daily water intake). The model of logistic regression correctly 
classified $80.2 \%$ of cases overall. We were able to correctly classify $82.6 \%$ of students who presented the water intake equal or more than 1.5 litres and $77.2 \%$ of students who presented water intake less than 1.5 litres.

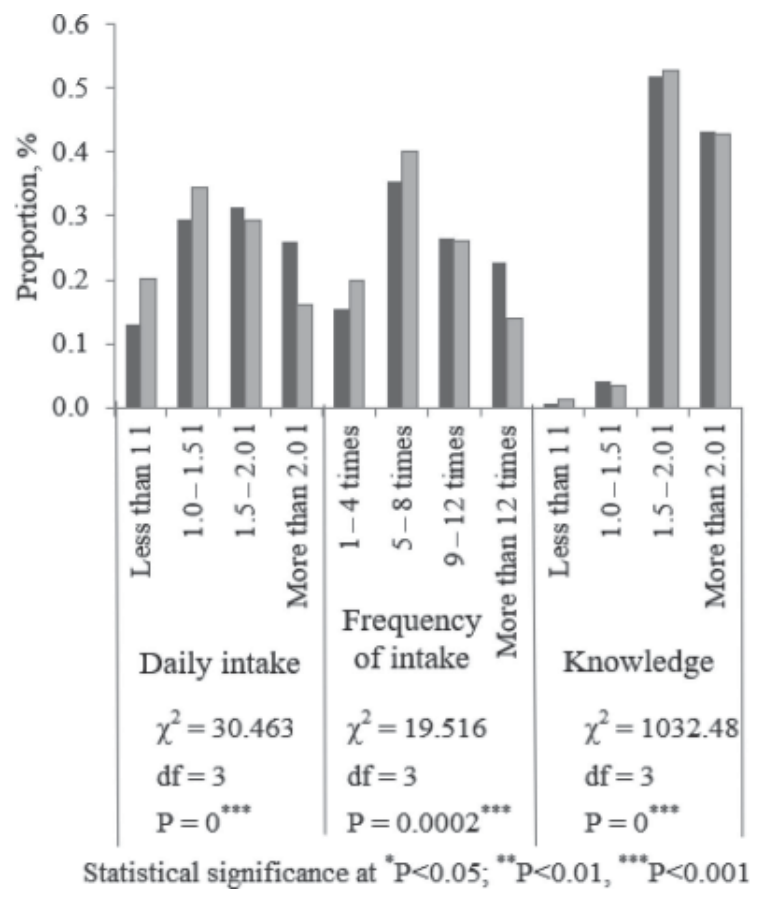

Fig. 1. The water intake, frequency of water consumption, and knowledge about recommended daily intake between groups of the Czech and Slovak students

: Czech Republic (n=2602); : Slovakia $(\mathrm{n}=418)$

Table 2. The most consumed types of beverages by students

\begin{tabular}{|c|c|c|c|}
\hline \multirow[t]{2}{*}{ Type of beverages } & \multicolumn{3}{|c|}{ Absolute and relative frequencies of students } \\
\hline & $\begin{array}{c}\text { Total } \\
\text { (Proportion, \%) } \\
\mathrm{n}=3020\end{array}$ & $\begin{array}{c}\text { The Czech Republic } \\
\text { (Proportion, \%) } \\
n=2602\end{array}$ & $\begin{array}{c}\text { Slovakia } \\
\text { (Proportion, \%) } \\
n=418\end{array}$ \\
\hline Plain tap water & $2814(0.932)$ & $2440(0.938)$ & $374(0.895)$ \\
\hline Plain non-carbonated packaged & $1473(0.488)$ & $1232(0.474)$ & $241(0.577)$ \\
\hline Tea & $2699(0.894)$ & $2311(0.888)$ & $388(0.928)$ \\
\hline Fruit/vegetable juices & $2054(0.680)$ & $1781(0.685)$ & $273(0.653)$ \\
\hline Coffee & $2002(0.663)$ & $1732(0.666)$ & $270(0.646)$ \\
\hline Regular soda or pop & $1699(0.563)$ & $1459(0.561)$ & $240(0.574)$ \\
\hline Sugar-sweetened beverages & $1196(0.396)$ & $1050(0.404)$ & $146(0.349)$ \\
\hline Flavoured water & $1066(0.353)$ & $931(0.358)$ & $135(0.323)$ \\
\hline Energy drinks & $366(0.121)$ & $323(0.124)$ & $43(0.103)$ \\
\hline Diet soda or pop & $302(0.100)$ & $269(0.103)$ & $33(0.079)$ \\
\hline Sports drinks & $286(0.095)$ & $265(0.102)$ & $21(0.050)$ \\
\hline Milk and milk drinks & $2257(0.747)$ & $1943(0.747)$ & $314(0.751)$ \\
\hline
\end{tabular}




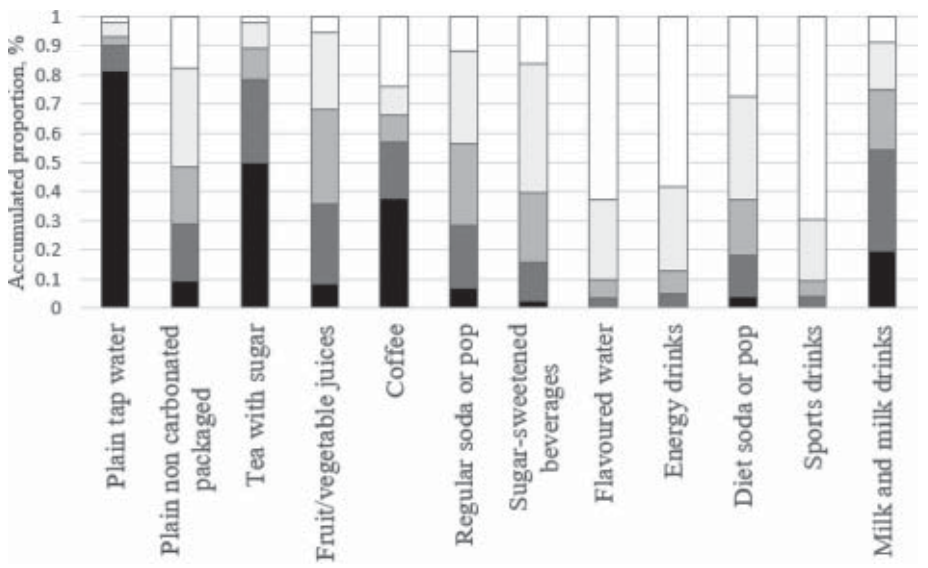

Fig. 2. The relative frequencies of the consumed types of beverages by students

口: Daily consuption; $\square$ : Several times a week; $\div$ : Several times a month; : Very rare consuption; $\square$ : No consuption

Table 3 gives us the information about the contribution or importance of each of our independent variables from logistic regression to the volumes of daily water intake. For $n=3020$, we have obtained eight statistically significant variables - gender, country, frequency of daily water intake, knowledge about recommended daily intake, factors of beverage preferences, regularity of drinking, taking the water to the school, and place of the most water intake. The results indicate that students reporting they have a daily water intake equal or more than 1.5 litres are more likely to be men than women, are more likely to be from the Czech universities, have a higher frequency of daily water intake, have a better knowledge about recommended daily intake, drink regularly, take the water to the school, and have the most water intake at home or in a dormitory. The odds of a person answering that he/she has a daily water intake equal or more than 1.5 litres, is 4.97 times higher for someone who reports a regularity of water intake per day $\left(95 \%\right.$ confidence interval $\left.3.93-6.29, \mathrm{P}=0.000^{* * *}\right)$.

The comparison of fluid intake characteristics (factors of beverage preferences, the regularity of drinking, taking the water to the school, and place of the most water intake) between the Czech and Slovak students is shown in Figure 3. Students have strong preferences for beverages, based on taste $(65.0 \%)$ and health effects $(22.7 \%)$ primarily, prices $(3.5 \%)$ and availability $(8.7 \%)$ were secondary. In total, $66.6 \%$ of students reported regular water intake. In total, $57.0 \%$ of students reported taking water to school ( $48.2 \%$ men, $62.9 \%$ women). The place of the most water intake is home or dormitory for $76.9 \%$ of students $(81.7 \%$ men, $73.7 \%$ women). The chi-square statistics for the fluid intake characteristics between groups of the Czech and Slovak students are shown in Figure 3.

We observed that the optimal fluid intake of more than 2 litres given by national authorities in the Czech Republic and Slovakia has been reported by $24.6 \%$ of all students, $26.0 \%$ of the Czech students and $16.1 \%$ of the Slovak students. These results are similar to 
findings from Šramková and KopČEKová (2005), KUKAČKA (2010), and JAKUBíKovÁ (2010). The fluid intake of less than 1 litre per day was observed for $14.1 \%$ of our respondents, $13.1 \%$ of the Czech students, and 20.1\% of the Slovak students. KuKAČKA (2010) presented 22\% for Czech students and JAKUBíKová (2010) reported 27\% for Slovak students.

Table 3. Logistic regression analysis of the determinants of recommended water intake per day

\begin{tabular}{|c|c|c|c|c|}
\hline \multirow{2}{*}{$\begin{array}{l}\text { Water intake } \\
\text { equal or more } \\
\text { than } 1.5 \text { litres } \\
\text { Gender }\end{array}$} & \multirow[t]{2}{*}{$\begin{array}{c}\text { P-value } \\
\text { (degrees of freedom) }\end{array}$} & \multirow[t]{2}{*}{$\begin{array}{l}\text { Adjusted } \\
\text { odds ratio }\end{array}$} & \multicolumn{2}{|c|}{$\begin{array}{l}95 \% \text { confidence interval for } \\
\text { adjusted odds ratio }\end{array}$} \\
\hline & & & & \\
\hline Female & $0.000^{* * *}(1)$ & 0.253 & 0.200 & 0.318 \\
\hline Male & & 1 & & \\
\hline Year of study & $0.253(1)$ & 1.040 & 0.972 & 1.112 \\
\hline Frequency of intake & $0.000^{* * *}(1)$ & 3.135 & 2.775 & 3.542 \\
\hline Knowledge about intake & $0.000^{* * *}(1)$ & 1.924 & 1.629 & 2.272 \\
\hline Knowledge about coffee & $0.849(1)$ & 0.965 & 0.672 & 1.386 \\
\hline \multicolumn{5}{|l|}{ Country } \\
\hline Slovakia & $0.030^{*}(1)$ & 0.708 & 0.519 & 0.967 \\
\hline The Czech Republic & & 1 & & \\
\hline Study area & $0.136(3)$ & & & \\
\hline Humanities and Arts & $0.430(1)$ & 1.144 & 0.819 & 1.598 \\
\hline Engineering and Technologies & $0.996(1)$ & 1.001 & 0.706 & 1.420 \\
\hline Natural Sciences & $0.177(1)$ & 0.744 & 0.484 & 1.143 \\
\hline Medicine and Health Sciences & & 1 & & \\
\hline Factors of beverages preferences & $0.009^{* *}(3)$ & & & \\
\hline Health effects & $0.001^{* *}(1)$ & 1.486 & 1.168 & 1.891 \\
\hline Price & $0.439(1)$ & 0.820 & 0.495 & 1.357 \\
\hline Availability & $0.799(1)$ & 1.046 & 0.739 & 1.481 \\
\hline Taste & & 1 & & \\
\hline Regularity of drinking & $0.000^{* * *}(1)$ & 4.973 & 3.932 & 6.289 \\
\hline Taking the water to the school & $0.000^{* * *}(3)$ & & & \\
\hline Place of the most water intake & $0.037^{*}(2)$ & & & \\
\hline School & $0.071(1)$ & 0.796 & 0.622 & 1.020 \\
\hline Restaurant or cafeteria & $0.048^{*}(1)$ & 0.598 & 0.359 & 0.996 \\
\hline Home or dormitory & & 1 & & \\
\hline
\end{tabular}

Statistical significance at $* \mathrm{P}<0.05 ; * * \mathrm{P}<0.01, * * * \mathrm{P}<0.001$ 


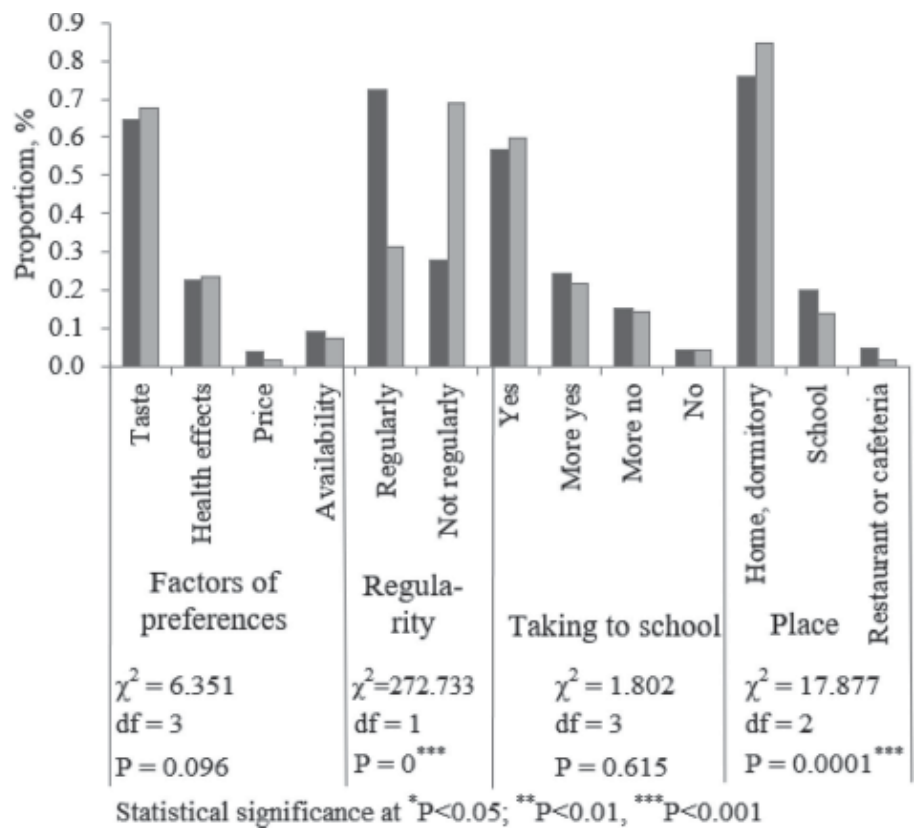

Fig. 3. Fluid intake characteristics between groups of the Czech and Slovak students ㅁ: Czech Republic $(\mathrm{n}=2602) ;$ : Slovakia $(\mathrm{n}=418)$

\section{Conclusions}

We have analysed a sample of the 3020 university students from the Czech Republic and Slovakia to evaluate their daily fluid intake and to determine the characteristics of beverage consumptions. Our results showed that students have strong preferences for beverages, based on taste and health effects primarily, prices and availability were secondary. We found significant statistical differences between Slovak and Czech students for several characteristics regarding fluid intake.

We recommend for the age group of 19 to 26 years to drink plain water or low-calorie beverages instead of sugar-sweetened beverages; to carry a water bottle and refill it throughout the day; to eat vegetables and fruits, to drink extra water to cover fluid loss before, during, and after an exercise and intensive physical performance; to check the adequate fluid intake by colourless or light yellow urine.

Our future research directions should include the analysis of other influencing factors of water requirements, among them climate or physical activity. The fluid intake and beverage consumption of students can vary by the season of investigation. The comparison of results with other countries in Europe (e.g. Hungary or Poland) might be fruitful. There is also a gap in research on the effect of drinking water provision and promotion on student beverage intake.

We would like to kindly thank the reviewers for their fruitful and proper suggestions on the paper. 


\section{References}

AN, R. \& MCCAFFreY, J. (2016): Plain water consumption in relation to energy intake and diet quality among US adults, 2005-2012. J. Hum. Nutr. Diet, 29(5), 624-632.

Balaghi, S., Faramarzi, E., Mahdavi, R. \& Ghaemmaghami, J. (2011): Fluids intake and beverage consumption pattern among university students. Health Promot. Perspect., 1(1), 54-61.

Block, J.P., Gillman, M.W., Linakis, S.K. \& Goldman, R.E. (2013): “If it tastes good, I'm drinking it”: Qualitative study of beverage consumption among college students. J. Adolescent Health, 52(6), 702-706.

Ferreira-PÊgo, C., Ninssensohn, M. \& Kavouras, S.A. (2016): Beverage intake assessment questionnaire: relative validity and repeatability in a Spanish population with metabolic syndrome from the PREDIMED-PLUS study. Nutrients, $8,475$.

JAKUBíKovÁ, M. (2010): Zdravie a stravovanie študentov ošetrovatel'stva. (Health and nutrition of nursing students) Zbornik, Healthy lifestyle in the context of education in schools I., Prešov, Slovakia. pp. 21-24.

KuKaČKA, V. (2010): Udržitelnost zdraví. (Health sustainability.) 1st ed. České Budějovice: University of South Bohemia. 228 pages

MALIK, V.S. (2019): Non-sugar sweeteners and health. BMJ, 364, k5005.

Nissensohn, M., Castro-Quezada, I. \& Serra-Majem, L. (2013): Beverage and water intake of healthy adults in some European countries. Int. J. Food Sci. Nutr., 64(7), 801-805.

Park, S., Blanck, H.M., Sherry, B., Brener, N. \& O’Toole, T. (2012): Factors associated with low water intake among US high school students - National youth physical activity and nutrition study, 2010. J. Acad. Nutr. Diet, 112(9), 1421-1427.

PHA SR (2018): Public Health Authority of the Slovak Republic. Viete si vybrat' vodu pre pitný režim? (Can you select water for drinking?) Available at http://www.uvzsr.sk/index.php?option=com content\&view=article\&id=3546:uvz-sr-viete-si-vybra-vodu-pre-pitny-reim\&catid=95:informacie-prespotrebiteov (last accessed 13 June 2020)

Rosborg, I. \& KožíšEK, F. (2016): Drinking water minerals and mineral balance. $1^{\text {st }}$ ed. Springer International Publishing, Cham, Switzerland. 175 pages

ŠrRAMKOVÁ, K. \& KoPČEKOvÁ, J. (2005): Rizikové faktory civilizačných chorôb súvisiace so stravovacími zvyklost’ami a fajčiarskymi návykmi u vysokoškolských študentov. (Risk factors of civilisation diseases pertinent to boarding and smoking habits in university students.) Risk factors of food chain V., Nitra, Slovakia. pp. 301306.

Vanderlee, L., Reid, J.L., White, C.M., Hobin, E.P., Acton, R.B., ... \& Jones, A.C.O. (2018): Evaluation of the online beverage frequency questionnaire (BFQ). Nutr. J., 17, 73. 